\title{
The Role of Children's Rights in Regulating Digital Advertising
}

Dr. Valerie Verdoodt, KU Leuven Centre for IT and IP Law

\begin{abstract}
An important domain in which children's rights are reconfigured by internet use, is digital advertising. New advertising formats such as advergames, personalised and native advertising have permeated the online environments in which children play, communicate and search for information. The often immersive, interactive and increasingly personalised nature of these advertising formats makes it difficult for children to recognise and make informed and well-balanced commercial decisions. This raises particular issues from a children's rights perspective, including inter alia their rights to development (Article 6 UNCRC), privacy (Article 16 UNCRC), protection against economic exploitation (Article 32 UNCRC), freedom of thought (Article 17 UNCRC) and education (Article 28 UNCRC). The paper addresses this reconfiguration by translating the general principles and the provisions of the United Nations Convention on the Rights of the Child into the specific context of digital advertising. Moreover, it considers the different dimensions of the rights (i.e. protection, participation and provision) and how the commercialisation affects children and how their rights are exercised.
\end{abstract}

\section{Keywords}

Children's rights, digital advertising, advertising literacy, privacy, development, commercial decision-making 


\section{New forms of digital advertising reconfigure children's rights}

Across the world, children are engaging in digital environments in which they play, communicate and search for information. According to LIVINGSTONE et al., 'an estimated one in three of all Internet users in the world today is below the age of 18' (Livingstone et al. 2015). Children are early adopters of information and telecommunications technologies, which have a crucial role in empowering them by enabling communication and education. They access the web via their own devices or ask their parents to borrow theirs to go online. Since the creation of the United Nations Convention on the Rights of the Child ("UNCRC"), there has been general agreement concerning children's entitlement to fundamental rights that are of importance in the (digital) media environment (Lievens 2014). The Council of Europe highlights in its Strategy on the Rights of the Child (20162021) that information and communication technologies affect the enjoyment of their fundamental rights (Council of Europe 2016a). Indeed, the digitisation of children's media lifeworlds significantly influences not only how they can exercise their rights, but also how these rights may be supported or neglected (Third et al. 2014). Every children's right now has a digital dimension and as such the principles and provisions of the children's rights framework should be looked at through a digital lens (UN Committee on the Rights of the Child 2014; Lievens et al. 2018).

An important domain in which children's rights are reconfigured by internet use, is advertising and marketing (Livingstone et al. 2015). Children are an attractive target group for advertisers, as they not only represent the primary market (i.e. they can purchase products or services with their weekly allowance), but also the secondary market (i.e. influence on their parents' purchasing behaviour) and even the so-called future market (i.e. themselves as adults with full commercial decision-making capacities). From a very young age, they already display some level of brand consciousness, even starting from the age of 2 years old (Gunter 2016). Accordingly, advertisers and marketers target children from the earliest stages of their lives, transforming children into child-consumers.

The persuasive tactics employed by the advertising industry become ever more sophisticated, and it is difficult for children to recognise commercial messages from editorial content online. Furthermore, due to technological advancements and increasing computational capacities, children are being tracked online and their personal data is used to target them with personalised commercial messages. This commercialisation of children's digital environments impacts not only how children can exercise their rights but also how these rights may be protected, promoted or neglected. In order to address this reconfiguration of children's rights and adapt to the new reality - children as early adopters of new technologies accessing commercialised digital environments for play, communication and information from a very young age - a specific interpretation of the relevant provisions of the UNCRC framework is needed. 


\section{Persuasive tactics in the digital era}

The most significant difference between traditional and digital advertising lies in the type of persuasive tactics that are employed. Traditional formats (e.g. TV commercials) primarily spread factual or propositional messages, for instance by focusing on the product quality and characteristics (Moore and Rideout 2007). In addition, certain persuasive tactics are used, including inter alia repetition and linking them to positive stimuli such as humour (Rozendaal, Buijzen, et al. 2011). Conversely, new formats (e.g. advergames, sponsored content on social media) employ more subtle tactics. According to DE PAUW et al., these tactics function at preconscious level (i.e. unrepressed and easily recalled), and rather than aiming to inform consumers about products and services they attempt to effectuate a better brand recall and attitude (De Pauw et al. 2017). This is achieved through constant exposure to brands or products, as well as through implicit persuasion by what NAIRN and FINE define as a 'positive affect transfer' of amusing and captivating media content to the brand or product it integrates (Nairn and Fine 2008). The specific tactics of new forms of digital advertising, including their (1) immersive, (2) interactive, (3) personalised nature as well as (4) their emotive appeal, are particularly appealing to children (Nairn and Fine 2008; Buijzen et al. 2010; Daems and De Pelsmacker 2015; Zarouali et al. 2016). They allow for a more effective persuasive commercial message, as they positively influence children's attitudes towards products or brands and have a real impact on their purchasing decisions. In light of this, it remains crucial for children to be able to recognise and understand the persuasive tactics of these new forms of digital advertising.

A first widespread persuasive tactic in this area is the fluid integration of commercial messages into non-commercial content (i.e. a programme or editorial content). Although this process of convergence has started quite some time ago, it reached new heights within the digital environment (Grimes 2008). The idea behind integration is that commercial communication is most effective when the consumer does not recognise it as such (Calvert 2008). When children are exposed to branded environments for an extended period of time, the lines between advertising and programme content are blurred (Daems and De Pelsmacker 2015). By seamlessly integrating the commercial message in the storyline and the images of the media content, potential irritation or resistance on the child's behalf may be bypassed. Indeed, integrated advertising techniques avail themselves of the fact that consumers are unable to entirely ignore the commercial message, as it is inherently linked with the informational element (Hellemans et al. 2015). The societal impact of the blurred lines between commercial and noncommercial content is significant. Consumers may experience greater difficulties when it comes to recognising the persuasive commercial messages, which undermines their ability to process the message critically (Rozendaal, Lapierre, et al. 2011; Cauberghe et al. 2012). According to the Organisation for Economic Cooperation and Development (“OECD”), 'Children have insufficient understanding of how Internet content is produced and financed, which is also a reason why they have difficulties critically assessing advertising messages' (OECD 2012). This trend in digital advertising has become even more popular due to consumer fatigue and immunity to traditional digital advertising (such as display ads) and the increased use of ad blocking technologies (Clifford and Verdoodt 2016). 
Secondly, advertising formats that are highly interactive such as advergames or branded mobile applications have proven to be an extremely useful tool for advertisers and in particular when targeted towards children. Such techniques allow for the development of a positive product or brand association through the delivery of fun interactive content (Nairn and Hang 2012; Cheyne et al. 2013). As a result, children are no longer merely passive receivers of commercial messages. Instead, they become actively involved in the advertising process for instance by creating or sharing content themselves or by networking with peers (Montgomery and Chester 2009; Daems and De Pelsmacker 2015). Indeed, advertisers stimulate young consumers to share and create content in order to promote their own brands, products and services within children's personal networks (Daems and De Pelsmacker 2015) (for instance, children are encouraged to create and share Tik-Tok videos of brand songs with their friends).

Moreover, digital advertising has become increasingly personalised and advertisers are progressively interested in the personal information of their young customers (EDPS 2012; Global Privacy Enforcement Network 2015). Advertisers target children with personalised advertisements and tailor their marketing campaigns based on children's online behaviour. The commercial message can be transmitted more effectively as advertisers can respond explicitly to a specific user's developmental level and knowledge base. This is a distinct advantage when it comes to building a strong and lasting personal interaction and connection with the child consumer (Cauberghe et al. 2012). Furthermore, as children are now tracked and monitored in their daily lives, they are also targeted based on their location (i.e. real-world behavioural targeting). Especially adolescents, a group of avid social media users, are frequently exposed to behavioural advertising on social media platforms.

Finally, although one can argue that all commercial communications to a certain extent aim to have an emotional effect, this is especially the case with newer forms (and in particular with interactive and/or personalised forms of digital advertising). Important to note is that highly affective media content does not motivate children to process the content critically. Indeed, as children need all their cognitive capacities to process and understand the media content, they do not have the capacity to critically evaluate the commercial message (An and Stern 2011; Rozendaal, Lapierre, et al. 2011; Waiguny et al. 2014).

The sophistication and effectiveness of these new trends in digital advertising aimed at children paired with children's lower level of advertising literacy has significant implications from a children's rights perspective. Advertising literacy entails the skills, knowledge and abilities of children to deal with ads, including their knowledge of the persuasive intention of advertising in general, their affective attitude towards advertising (i.e. like or dislike) and their ability to develop an opinion regarding the appropriateness of specific advertising formats (Cauberghe et al. 2016).

\section{Gaps in the regulatory framework for digital advertising}

Although the aim of this article is to provide insights into the role of children's rights in regulating digital advertising, a brief account of the issues associated with the existing EU 
regulatory framework for commercial communications is given to provide some additional context. At the EU level there are several legislative and self-regulatory initiatives imposing a myriad of obligations on advertisers, first and foremost with regard to the identification of commercial communications, but also with regard to the content of the commercial message or the use personal data for advertising purposes. Relevant instruments at EU level include for instance the Audiovisual Media Services Directive, the e-Commerce Directive, the Unfair Commercial Practices Directive and the General Data Protection Regulation (for a complete overview see (Verdoodt 2018)). Aside from this, the advertising industry has been very active in developing self-regulation. However, the multitude of rules and obligations does not mean that, automatically, the level of protection and empowerment of children is high.

In earlier research, it has been argued inter alia that the existing protections for children in the context of new forms of commercial communication often revolve around identification and transparency requirements, essentially allocating much of the responsibility with children and their parents (e.g. advertisers have to label commercial messages, but it is up to children and parents to recognise and understand the meaning of these labels) (Verdoodt 2018; Verdoodt et al., 2016). Moreover, with regard to the processing of children's personal data for advertising purposes, the General Data Protection Regulation provides specific protection for children, but it remains unclear what this specific protection will entail in practice. The framework also does not contain a definition of a 'child', leading to uncertainty regarding the age group(s) to which certain protection measures should apply (Lievens and Verdoodt 2017; Verdoodt and Lievens 2017).

In light of this, it can be questioned whether the current regulatory mechanisms reflect commitments made by signatories to the United Nations Convention on the Rights of the Child. More specifically, several children's rights and principles are relevant in the context of digital advertising aimed at children. In the following section, these rights and principles are translated into standards for the regulatory framework for digital advertising.

\section{Translating the UNCRC in the context of digital advertising}

\subsection{Overarching principles that form a child rights perspective}

In the context of the UNCRC, the role of States lies in fulfilling clear obligations to each and every child. According to the UN Committee on the Rights of the Child ("UNCRC Committee"), States should develop a child rights perspective throughout their government, parliament and judiciary to achieve an effective implementation of the Convention (UN Committee on the Rights of the Child 2003). Such a perspective should consider the four key principles of the UNCRC, which form the basis for interpreting the other provisions. The principles highlight the fundamental values underlying the Convention and aim at ensuring a common philosophical approach. Each of the guiding principles remains relevant in the context of digital advertising. 


\subsubsection{Children's right to development as the core principle}

Perhaps the most fundamental human right's principle of the child is enshrined in Article 6 UNCRC, children's right to have their lives protected from the moment of birth, as well as their right to be able to survive, grow and develop appropriately. Article 6 is much broader than the mere survival of the child and should be interpreted in a comprehensive manner (Nowak 2005). Both the Convention in Article 27 and the UNCRC Committee in its General Comment no 5 on general measures for the implementation of the Convention, interpret development as a holistic concept, encompassing several dimensions (i.e. the physical, mental, spiritual, moral and social dimension) (UN Committee on the Rights of the Child 2003). Furthermore, the UNCRC Committee has often referred to development in its jurisprudence as the process of becoming an adult, during which the child develops 'normally' or in a 'healthy' manner (Peleg 2012).

Furthermore, PELEG stresses that during the drafting process of the Convention the discussions also focused on the desired result of the development process, namely the fulfilment of the child's human potential (Peleg 2012). First, the UNCRC strives for an optimal approach, for instance with Article 29 UNCRC, which defines the aims of education, requiring that education enables the child to develop to their fullest potential. In this sense, it has been argued that children have 'the right to become an optimal person' (UN Committee on the Rights of the Child 2003; Willems 2007). Article 6 is understood as the platform for other developmental principles enshrined in the Convention, such as the best interests of the child and the evolving capacities of the child principles, as well as for other rights that may enable children to reach their fullest potential, including inter alia the right to information and freedom of thought, school and educational goals and the right to participation in leisure and play (UN Committee on the Rights of the Child 2001; Lansdown 2005). This perspective also recognises children as individuals and allows taking into account their inner capacities and their opinions on what they consider to be in their best interest (UN Committee on the Rights of the Child 2003). As there is no one right way to develop, the right to optimal development recognises that every child has different experiences and will therefore develop in different ways, as long as it enables the child to fulfil his or her potential (Peleg 2012).

The optimal development theory has been contested by scholars arguing that reality forces us to be more modest in our ambitions. A minimal approach is advocated, which attempts to temper high expectations and to better connect with the relative autonomy of children and their rights, and the responsibility of parents in this regard, while preventing excessive government interference (Weijers 2014). WEIJERS argues that if the optimal development of the child is the desired outcome of the development process, it would lead to paternalistic intervention by the government in the lifestyle and parenting methods of parents, and in his opinion the government should only intervene when needed to prevent damage to the development of the child. Nevertheless, LIEFAARD stresses that this view is too narrow in light of the UNCRC and, therefore, advocates a children's rights approach, which takes into account children's healthy and holistic development (as promoted by the UNCRC), as well as the concerns of paternalism and too high expectations of governments (Liefaard et al. 2016). 
The right to development under the UNCRC also has different dimensions that need consideration. The UNCRC Committee emphasises that children should be able to develop the necessary life skills to face the challenges they can expect to be confronted with in real life (UN Committee on the Rights of the Child 2001). These life skills include the ability to make balanced decisions, resolve conflicts in a peaceful manner, be a critical thinker etc. Thus, in order to be in line with the underlying child's right to develop to their fullest potential, children should be educated and empowered to cope with digital advertising (i.e. advertising literate) so that they can grow up to be critical, informed consumers who make their own conscious choices in today's new media environment. However, the sophistication, immersiveness and opaqueness of modern advertising practices provides a significant challenge in this respect. Therefore, it can be argued that children need protection against those advertisements that they do not recognise as such and cannot critically process, thereby rendering it impossible for them to make a balanced commercial decision, and ultimately having a negative impact on their right to development. As per the UNCRC Committee,

children, as users of information technologies and recipients of information, may be exposed to actually or potentially harmful advertisements, spam, sponsorship, personal information and content which is aggressive, violent, hateful, biased, racist, pornographic, unwelcome and/or misleading (UN Committee on the Rights of the Child 2011).

The Committee further discussed this topic during its Day of general discussion on digital media and children's rights in 2014. During the discussions, it was suggested to align the Committee's position with the UN Special Rapporteur in the field of cultural rights. The latter had recommended State parties to adopt legislation, which would 'prohibit all forms of advertising to children under 12 years of age, regardless of the medium, support or means used, with the possible extension of such prohibition to 16 years of age and to ban the practice of child brand ambassadors' (UN Committee on the Rights of the Child 2014). However, the child's right to development also has an important participation dimension that should be kept in mind. According to FORTIN, children will be unable to make a successful transition to adulthood unless they are given opportunities to practice their decision-making skills and are provided with a dry-run of adulthood (Fortin 2003). From this perspective, banning all forms of advertising aimed at children would not be compatible with the right to development. The European Parliament advocates a more nuanced approach, by stressing that children need to be protected against harmful practices such as aggressive or misleading advertising (e.g. advertising which encourages overspending and the purchase of virtual goods or credits with their mobile phones) (European Parliament (Committee on Culture and Education) 2012).

\subsubsection{No discrimination in advertising or marketing}

Article 2 UNCRC protects children against all forms of discrimination. It stems from the underlying idea that all children are born with fundamental rights and freedoms and should not be discriminated against for being children, or on any other basis (e.g. gender, race, religion). According to ABRAMSON, the right to non-discrimination is an umbrella right and, as such, it attaches to or forms part of other rights of the Convention (Abramson 
2008). All rights apply to all children without exception, and it is up to the State to put into place protection mechanisms and take positive actions to promote children's rights free of discrimination.

In a commercial context, the principle requires equality of children as consumers, who need to be protected from (age) discrimination in access to inter alia facilities, services, information and goods. VAN DER HOF and PRINS warn in this regard that profiling and personalisation techniques allow service providers to restrict access to certain services to specific (groups of) consumers, such as minors or consumers with a low level of income (van der Hof and Prins 2008). Moreover, personalisation may result in differential treatment of consumers, for instance through price differentiation (van der Hof and Prins 2008; Kirsch 2011) or by restricting consumer choice and diminishing preferences (van der Hof and Prins 2008). The media and advertising industries have an important role to play in facilitating access to the digital commodities children need to exercise their participation rights (e.g. right to freedom of assembly, right to freedom of expression and information).

Another element to consider is that marketing and advertising campaigns, both offline and online, often contain stereotypes and discriminatory messages (for instance based on gender). Children are particularly vulnerable to such practices as they learn by imitation and mimicking and, as such, discrimination in advertising may have a significant impact on children's development and how they view themselves. In order to battle gender discrimination in digital media, the COUNCIL OF EUROPE recently called on the Member States to take action and promote equality. The advertising industry, as well as providers of new media such as social networks or video-sharing platforms may also play an important role here (Council of Europe, Parliamentary Assembly 2016).

\subsubsection{The best interests of the child as a primary consideration for advertisers}

Article 3 UNCRC requires that the best interests of the child shall be a primary consideration in all actions concerning children. As such, the principle requires governments, public and private bodies to conduct child impact assessments and evaluate the impact of any proposed law, policy or decision on children's rights (UN Committee on the Rights of the Child 2003), including rules on digital advertising. According to EEKELAAR, best interests should be understood as:

Basic interests, for example to physical, emotional and intellectual care, developmental interests, to enter adulthood as far as possible without disadvantage; autonomy interests, especially the freedom to choose a lifestyle of their own (Eekelaar 1994).

The UNCRC Committee clarifies that a best interests assessment consists in 'evaluating and balancing all elements necessary to make a decision in a specific situation for a specific individual child or a group of children' (UN Committee on the Rights of the Child 2013c). The principle also requires that States must ensure that the best interests of the child are taken as a primary consideration in decisions and actions undertaken by the private sector. In the context of digital advertising, this could be interpreted as requiring 
that the parties involved in the advertising chain must consider the best interests of children when developing advertising and marketing campaigns targeting this particular group of consumers (Verdoodt and Lievens, 2017).

\subsubsection{Consulting children in the development of digital advertising campaigns}

The fourth guiding principle of the children's rights framework can be found in Article 12 UNCRC, the right to be heard. The principle entails that children should be able to actively participate in the promotion, protection and monitoring of their rights. The UNCRC Committee explains that this means that children should have a voice in the decisionmaking, policymaking and the preparation and evaluation of laws and measures concerning them (UN Committee on the Rights of the Child 2009). The notion of participation highlights the need for dialogue and information-sharing between children, adults and other stakeholders, so that children can learn how their views can shape the outcome of such processes. The second paragraph of Article 12 requires that children's views need to be given due weight in accordance with their age and level of maturity. In other words, if the child matures, his or her views shall have increasing weight, for instance in the assessment of a child's best interests (UN Committee on the Rights of the Child 2013c). To achieve children's participation online, they should not only be consulted when developing legislation or policies (e.g. initiatives fostering safe use of digital media), but also when setting up services and other measures relating to digital media and ICT, and hence by the industry (UN Committee on the Rights of the Child 2014). This also applies to advertisers, who need to consult children when developing digital marketing campaigns for children (e.g. in the context of personalised advertising this means consulting children when carrying out a data protection impact assessment) (Verdoodt and Lievens, 2017). The age and level of maturity of the child will also play an important role in such an assessment.

\subsection{Children's rights reconfigured by new forms of digital advertising}

\subsubsection{Children's autonomy and commercial decision-making}

\section{a) Influencing children's decision-making through advertising}

New advertising and marketing techniques have an increasing impact on society's cultural values as well as individuals' beliefs and aspirations (e.g. food consumption, tastes, beauty canons). In this regard, the UN General Assembly Special Rapporteur in the field of cultural rights reports that

the dominance of specific narratives and world views promoted through commercial advertising and marketing in public spaces, family and private spheres, combined with an increased deployment of techniques that may influence people at a subconscious level, raises particular concerns in terms of freedom of thought, opinion and, more widely, cultural freedom (Shaheed 2014).

Children's right to freedom of thought, conscience and religion is enshrined in Article 14 UNCRC. As part of their development process, children need access to information to form and formulate their opinions. The practical implementation of the freedom of thought is, 
therefore, intertwined with other children's rights such as inter alia the right to access to mass media sources and right to freedom of expression. Article 14 is aimed at state parties, who must ensure the specific right for children, by adopting legislation and taking measures (Brems 2006). Significant to note, is that restrictions on the freedom of thought are not allowed, contrary to for instance the freedom of expression (Hodgkin and Newell 2007).

Children may face the risk of being manipulated if it is unclear to them that certain information, content or entertainment is in fact a persuasive commercial message. An illustration can be found in children's changing food choices, as research has revealed that children who played advergames promoting less healthy foods were more likely to select less healthy food options than those who played advergames promoting healthier food options, which may lead to long term health concerns such as obesity (Montgomery and Chester 2009). Furthermore, it has been argued that the ubiquity of commercial messages in children's lives and the promotion of lifestyles based on consumption may lead them to become more materialistic and attach more value to money (Opree et al. 2014). According to ARNOULD and THOMPSON, individual consumers (including children) operate within a sociocultural, economic and political framework that shapes their thinking patterns and feelings in the marketplace (Arnould and Thompson 2005). New advertising and marketing techniques arguably help shape this framework for children from a very young age. In this regard, the Special Rapporteur also underlines the potential risk of normalising commercialisation when embedding marketing and advertising programmes in the school environment (Shaheed 2014). To conclude, it is contented that advertising calls into question children's ability to make informed commercial decisions, which may have long-lasting effects on their development. The influence that digital advertising may assert over children's decision making, necessitates an assessment of the means used by the advertising industry, considering children's rights, including their right to freedom of thought.

\section{b) Targeting children with personalised advertising}

The right to privacy is crucial in a digital media environment, where advertisers target children with commercial messages in their personal sphere, through their mobile phones, tablets, or even their connected toys. Article 16 of the UNCRC protects children from arbitrary or unlawful interferences with their privacy, family, home or correspondence, nor should there be unlawful attacks on their honour and reputation, which is considered inherent in any truly democratic society. This entails interferences by state authorities as well as private organisations (Hodgkin and Newell 2007). Moreover, paragraph 2 stipulates that there should be legislation in place which protects children against such interferences.

The advancements in internet technologies have led to the further commercial encroachment on children's private sphere (Verdoodt et al. 2016). Increased computing capabilities allow commercial entities to profile children's online behaviour and preferences, based on which children are targeted with tailored advertisements. It has been argued that the right to privacy has different dimensions in the digital environment which need to be considered, namely a protection and participation dimension (Lievens 
et al. 2018). On the one hand, children's private lives should remain free from unreasonable constraints from the State or from other actors such as commercial entities online. In relation to the latter, children often do not grasp the scope of the underlying data processing activities and business models of online actors. According to the OECD, children lack the awareness and capacity to foresee the potential long-term privacy consequences of the disclosure of their personal data online (OECD 2012). Moreover, research has shown that children generally consider themselves having a right to privacy online from their parents or peers (i.e. social privacy), rather than from the State or commercial intrusion (e.g. tracking for behavioural advertising purposes) (Lievens et al. 2018). As a result, they form a particularly vulnerable group of online users that require protection.

On the other hand, the right to privacy has an important participatory dimension, as it is essential for individual autonomy and self-determination, and a precondition of participation. This relates to having control over the aspects of the identity one wants to project to the outside world, or according to ROUVROY and POULLET more fundamentally

the capacity of the human subject to keep and develop his personality in a manner that allows him to fully participate in society without however, being induced to conform his thoughts, beliefs, behaviours and preferences to those thoughts, beliefs, behaviours and preferences held by the majority (Rouvroy and Poullet 2009).

In other words, the right to privacy, together with the right to data protection (Article 8 Charter of Fundamental Rights of the EU), aim at safeguarding the human capacity for reflexive self-determination (Richards 2016) and, as such, also link to the child's participation rights to freedom of expression and freedom of thought. In this regard, SAVIRIMUTHU warns that the increased role of algorithms in defining children's consumer experience should not disregard the value of a child's emotional space, which should not be subject to the inside the box-thinking that constitutes profiling-based decisions (Savirimuthu 2014). Profiling and behavioural targeting have the capacity not only to compartmentalise children, but also to shape their preferences and interests accordingly, ultimately affecting their autonomy and development (Verdoodt and Lievens 2017). The right to development in such a digital and commercialised setting entails that children's basic needs are fulfilled, so that they can develop into independent adults. According to ARIELY and BERNS, the creation of profiles has a potential negative impact on the development of children, as the collection and use of personal data for the purpose of profiling may undermine children's rights to experiment freely with and critically reflect upon their interactions, as the digital environment they are exploring and are communicating in is no longer free of supervision and tracking (Ariely and Berns 2010). In that regard, the lack of children's control over the management of their personal data also affects their ability to develop, learn and experiment with their own identity (Savirimuthu 2014).

In this context, there is an important tension between participation and protection, which States should keep in mind when developing guidance documents and policies for the processing of children's personal data. On the one hand, States should develop guidelines 
for increased transparency and raise awareness of profiling activities and behavioural advertising, both amongst children and parents. On the other hand, States should consider default limits to the processing of children's personal data for the creation and use of profiles. Here too, the age and level of maturity of the child will play an important role (Verdoodt and Lievens 2017). Companies collecting children's personal data for advertising purposes must also take their responsibility (Montgomery and Chester 2015) and carry out a thorough data protection impact assessment with attention to the interests and rights of children. Finally, it should be kept in mind that parents keeping track of a child's use of the Internet and other new media or their digital correspondence, for instance through software, could constitute a violation of the child's right to privacy (Lievens 2010). When deciding on the use of such paternalistic measures, parents should take the child's best interests into consideration, and consult the child about the information that is disclosed to their parents, in accordance with their age and maturity.

\section{c) The increased commercialisation of children's digital media and play}

Over the years, the digital environment has evolved into an important gateway to information, communication and entertaintment for children (Council of Europe 2016b). The increased commercialisation of this environment significantly impacts a number of children's rights.

First, children have a right to access to a diversity of media and information under Article 17 UNCRC. This article requires States to provide children with access to 'information and material from a diversity of national and international sources, especially those aimed at the promotion of his or her social, spiritual and moral well-being and physical and mental health'. The reasoning behind this provision is that for the exercise of other fundamental rights (e.g. the right to freedom of expression, the right to be heard), children need to have access to media and information. According to WhEATLY SACINo, the essence of Article 17 is the diversity in mass media sources, and State's duty to ensure that children and adolescents have access to 'a variety of producers and disseminators of movies, television and radio programs, books, magazines, the Internet and other mass media communications' (Sacino 2011). In addition, States have a series of obligations for encouraging other actors to produce and distribute material that promotes children's and adolescents' well-being, which arguably could include the advertising industry. The increased commercialisation of children's digital media poses certain challenges for the implementation of Article 17 in practice. First, digital media may transmit commercial messages that are harmful to children (i.e. protection). For instance, when harmful products or services are promoted, such as gambling, alcohol or unhealthy foods, or when portraying unrealistic body images (UN Committee on the Rights of the Child 2013a). Second, the increased personalisation of digital services and tailoring advertising messages on the basis of personal data may in practice result in a restricted consumer choice (i.e. provision). Finally, Article 17 also requires States to provide children with ageappropriate information on their rights (i.e. provision), which may be difficult to achieve in practice. To overcome such challenges, States are encouraged to pursue a proactive policy that stimulates the cultural, educational and informational potential of media when it comes to children, not only in relation to media content, but also regarding advertising aimed at them (Voorhoof 1994). Such a policy should focus inter alia on protecting the 
child against harmful commercial influences through the media and on safeguarding children's access to a diversity of information and media sources. In addition, parents also have an important responsibility to offer appropriate direction and guidance to children (in a manner consistent with the evolving capacities of the child) when exercising their rights. This provision could be interpreted as implying that parents have a responsibility to (do their best to) support their children in their approach to new media and advertising. Furthermore, Article 18 para 2 UNCRC provides that States must 'render appropriate assistance to parents and legal guardians in the performance of their childrearing responsibilities'. This 'assistance' could, for example, consist of States providing adequate information to parents, regarding the risks of certain media or advertising to which their children can be exposed (Hodgkin and Newell 2007).

Second, Article 31 UNCRC explicitly recognises the importance of play and recreation in children's lives, due to its positive impact on the social, cognitive and personal development of the child. More specifically, Article 31 requires States to 'recognize the right of the child to rest and leisure, to engage in play and recreational activities appropriate to the age of the child and to participate freely in cultural life and the arts'. New media technologies like social networking, mobile apps and online games can play an important role in this by facilitating access to a variety of playful, social, cultural and artistic activities. The UNCRC Committee has underlined that:

Children in all regions of the world are spending increasing periods of time engaged in play, recreational, cultural and artistic activities, both as consumers and creators, via various digital platforms and media, including watching television, messaging, social networking, gaming, texting, listening to and creating music, watching and making videos and films, creating new art forms, posting images (UN Committee on the Rights of the Child 2013b).

In this regard, States are encouraged to develop policies and adopt measures that are needed to enable all children to take full advantage of the opportunities of the digital environment (e.g. access to the internet and new media technologies, education). Nowadays, children and their families are exposed to increased marketing and a commercialisation of play. It was one of the major concerns brought forward by the UNCRC Committee, during its Day of general discussion in 2014. The Committee highlighted that parents experience more and more pressure to purchase certain toys and games which may be harmful to their children's development. In addition, children themselves are being targeted by game and toy manufacturers, who embed commercial messages directly into children's gaming experiences both online and offline. Examples of such a marketing strategy include the delivery of commercial messages through in-game advertising, advergames, or even interactive, connected toys. As mentioned, the data processing activities underlying these advertising techniques go beyond children's understanding and therefore often happen without their or even their parents' meaningful consent (Lupiáñez-Villanueva et al. 2016). The Committee also fears that global marketing in this context can serve to weaken children's active participation in the traditional cultural and artistic life of their community. To overcome this, the Committee underlines that Article 31 requires specific actions of States in the context of marketing and media. More specifically, States 
must review their policies concerning the commercialisation of toys and games to children, including through children's television programmes and directly related advertisements, with particular regard to those promoting violence, girls or boys in a sexual way and reinforcing gender and disability stereotypes (UN Committee on the Rights of the Child 2013b).

Finally, States are also recommended to limit exposure to advertising during peak viewing hours for children.

\subsubsection{Broadening the notion of economic exploitation}

Article 32 UNCRC enshrines the right to protection against economic exploitation, which up until now has not received a lot of attention in relation to the digital environment. Although the Convention does not offer a definition of the notion 'economic exploitation', Article 32 is generally interpreted as the child's right to protection against child labour (Swepston 2012). However, it can be argued that this notion is perhaps much broader, especially in the digital era, and as such could be relevant in the context of advertising. The notion combines two distinct elements: (1) economic and (2) exploitation. First, 'economic' implies that there is a material interest, i.e. a certain gain or profit through the production, distribution or consumption of goods and services (UN Committee on the Rights of the Child 1993). The UNCRC Committee recognises that this material interest may have an impact on the economy of either the State, the community or the family. In the context of commercial communication, the economic element could be the fact that certain goods and services are advertised towards children, potentially leading to an increased consumption of the advertised goods or services and, hence an increased gain or profit for the brand or company. This material interest of the company in turn has a direct impact on the targeted child and its family (i.e. on their consumption pattern).

Secondly, according to the Committee's interpretation, 'exploitation' means 'taking unjust advantage of another for one's own advantage or benefit' (UN Committee on the Rights of the Child 1993). More specifically, this includes manipulation, misuse, abuse, victimisation, oppression or ill-treatment. In this regard, the OECD has stressed that children are exposed to significant consumer risks in the digital environment. Indeed, they may face inter alia

'embedded ads, privacy-invasive practices, age-inappropriate content, as well as the exploitation of their incredulity and inexperience resulting in economic risks such as overspending or online fraudulent transactions' (OECD 2012).

The UNCRC Committee has also pointed to the fact that as children are recipients of information, they may be exposed to 'actually or potentially harmful advertisements, spam, sponsorship, personal information' (UN Committee on the Rights of the Child 2011) In this regard, the Committee has recognised that States have an important role in adequately incentivising the advertising industry to adopt fair advertising and marketing practices:

States should ensure that marketing and advertising do not have adverse impacts on children's rights by adopting appropriate regulation and encouraging business 
enterprises to adhere to codes of conduct and use clear and accurate product labelling and information that allow parents and children to make informed consumer decisions (UN Committee on the Rights of the Child 2013a).

Thus, the right to protection against economic exploitation could be interpreted as an additional protection to children against harmful advertising including misleading, hidden or personalised advertising.

\subsubsection{Education, access to information and advertising literacy}

As mentioned, to be in line with the child's right to development children should not only be protected from harmful advertising, but also be educated and empowered (i.e. advertising literate). Articles 28 and 29 UNCRC contain the right to education and the aims of education. These rights have a dual dimension, on the one hand requiring States to provide access to educational information to all children and on the other hand to enable children to develop the life skills to optimally use such educational and informational sources and strengthen their capacity to enjoy the full range of human rights (Lievens et al. 2018). Considering this second dimension, children's education rights should be viewed in conjunction with the general principles and rights of the Convention, in particular the right to development, as well as children's right to freedom of expression and the right to freedom of association (Verheyde 2006). According to the Council of Europe, the process of developing skills to use new media and technologies should go hand-in-hand with learning about the enjoyment of children's rights and freedoms online (Council of Europe 2006).

Whereas Article 28 contains the right to education, Article 29 adds a qualitative meaning to it by establishing the aims of education, i.e. the holistic development of the full potential of the child (and as such linking back to the child's right to development) (Verheyde 2006). As children are in the process of becoming adults, their situation can always be perceived as one of education. Education in this sense goes far beyond formal schooling and entails according to the UNCRC Committee: 'the broad range of life experiences and learning processes which enable children, individually and collectively, to develop their personalities, talents and abilities and to live a full and satisfying life within society' (UN Committee on the Rights of the Child 2001). According to VERHEYDE, the life skills children are entitled to develop include inter alia the ability to make well-balanced decisions, to develop a healthy lifestyle and critical thinking (Verheyde 2006), which are all crucial when it comes to coping with new advertising and marketing techniques. Therefore, it is argued that children should also be enabled to become advertising literate adults, which means that they should be able to develop and use their advertising-related knowledge, attitudes, and skills, such as the ability to recognise commercial messages, to understand the persuasive intent of such messages, and to critically evaluate them, both offline and online (Rozendaal, Lapierre, et al. 2011). There is broad consensus that the digital environment offers many benefits for children's education and development, but also that education and literacy initiatives are crucial means to empower children in this environment. In this regard, States should also promote advertising literacy initiatives and develop policies considering the children's rights framework (Lievens et al. 2018). 
Another prerequisite for children's development is the right to freedom of expression (Article 13 UNCRC), a fundamental right in any democratic society and deemed 'one of the basic conditions for its progress and for the development of every man' (European Court of Human Rights 2001). This fundamental right has been included into a wide variety of international, European, and national legislative texts. Article 13 of the Convention stipulates that this right includes 'the freedom to seek, receive and impart information and ideas of all kinds, regardless of frontiers, either orally, in writing or in print, in the form of art, or through any other media of the child's choice'. The article has a broad scope of application and extends to all means of information sharing. As such, it will also be applicable to (commercial) information shared via the internet or any other (future) communication technology (Lievens 2010). According to SMITH, the right is important for the development of the child, and it should not be affected by the fact that children may not have the same capacities as adults (Smith 2015). The right to freedom of expression is not an absolute right, but restrictions must be provided by law and necessary 'for respect of the rights or reputations of others, or for the protection of national security or of public order, or of public health or morals' (para. 2). Furthermore, whenever restrictions are imposed, regard must be had for the child's best interests, and whether such limitation unduly restrict children's use of or access to certain types of expression (Smith 2015). However, finding the right balance between the freedom of expression and information, and the protection of minors can be difficult. Tackling certain content or commercial messages which are deemed harmful to minors could lead to unwanted sideeffects to the freedom of expression of adults, as they should be able to access the content freely (Lievens 2010), or even of advertisers who also have a right to freedom of commercial speech (Kabel 1994).

Finally, children also have the right to freedom of association and peaceful assembly, which could be relevant in a commercial and digital context (Article 15 UNCRC). Similar to the freedom of expression, the right to freedom of association is not absolute but restrictions should be in accordance with the law and need to be necessary in a democratic society. According to DALY, the scope of Article 15 should be understood as remarkably broad, encompassing children's family relationships, school attendance, rights in public places, etc. (Daly 2016). Moreover, it is argued that children need their right to associate with friends in public to be promoted by the Convention because they often have nowhere to go, both in an offline and online context (Lievens et al. 2018). In relation to the latter, the Council of Europe has clarified how the right applies in an online context (to all users, not just to children). More specifically, it entails the

freedom to choose any website, application or service in order to form, join, mobilise and participate in social groups; the right to protest peacefully online; and the freedom to use available online tools to participate in local, national and global public policy debates, legislative initiatives and public petitions and to participate in policy-making relating to how the Internet is governed (Council of Europe 2014).

Social media platforms can play an important role in the realisation of this participation right, as they offer clear opportunities for forming or joining groups. However, as the business models of these online platforms are usually based on the collection of user data 
and the provision of targeted advertising, they may also raise issues from a children's rights perspective (e.g. right to privacy, right to protection against economic exploitation). The fact that certain service providers restrict their services to young children may also negatively impact children's rights to participate in online public spaces. Moreover, children's ability to access content online should not be dependent on the acceptance of the tracking of activities across devices and websites.

\section{Conclusion}

Children's digital environments are increasingly permeated by new and highly effective forms of advertising. The United Nations children's rights framework awards children with important rights and principles, which function as a comprehensive framework in light of which the legislative or self- and co-regulatory framework on digital advertising aimed at children should be evaluated. As children's rights are reconfigured by digital advertising, the principles and provisions require a translation into specific standards in the online commercial context, not only for regulatory bodies and policy makers, but also for businesses addressing their advertising and marketing at children and even for parents.

The tension between the objectives of protection and participation of the child is clearly present in a commercialised digital environment. Indeed, misleading or aggressive advertising (e.g. on social media or via online games) or the collection of children's personal data (e.g. for purposes of profiling or behavioural advertising) raises significant issues for children's rights. In this regard, it is essential that all children (i.e. every person under 18 years) can rely on a customised level of protection. At the same time, the digital environment offers great opportunities for children's participation and the exercise of rights such as inter alia the right to education, right to freedom of assembly, right to play, etc. Therefore, a purely protectionist approach to regulating new forms of advertising should be avoided, as this would also raise key issues in relation to empowerment, the child's right to development and self-determination and its evolving capacities as a 'consumer'. Moreover, participation arguably has a protective function, as children will only be really empowered to cope with new advertising techniques if they are actively involved in the formulation, implementation and review of policies regulating such techniques, in accordance with children's right to be heard. In this regard, they should also be enabled to make their views and experiences of commercial risks and exploitation known, and mechanisms should be developed through which children can express concerns, but also by providing them with age- and format-specific information and services (Lievens et al. 2018). To conclude, any regulatory, business and even parental decision concerning advertising and marketing requires a balancing act of the different dimensions by the relevant actors. 


\section{References}

Abramson, Bruce. Article 2: The Right of Non-discrimination. (Brill, 2008).

An, Soontae, and Susannah Stern, "Mitigating the Effects of Advergames on Children: Do Advertising Breaks Work?", Journal of Advertising 2011 (40), 43-56. DOI:10.2753/JOA00913367400103 .

Ariely, Dan, and Gregory S. Berns, "Neuromarketing: the hope and hype of neuroimaging in business", Nature Reviews Neuroscience 2010 (11) 284-292. DOI:10.1038/nrn2795.

Arnould, Eric J., and Craig J. Thompson, "Consumer Culture Theory (CCT): Twenty Years of Research", Journal of Consumer Research 2005 (31) 868-882. DOI:10.1086/426626.

Brems, Eva, A Commentary on the United Nations Convention on the Rights of the Child Article 14: The Right to Freedom of Thought, Conscience and Religion. (Leiden, Boston: Martinus Nijhoff Publishers, 2006).

Buijzen, Moniek, Eva A. Van Reijmersdal, and Laura H. Owen, "Introducing the PCMC Model: An Investigative Framework for Young People's Processing of Commercialized Media Content", Communication Theory $2010 \quad$ (20), 427-450. DOI:10.1111/j.14682885.2010.01370.x.

Calvert, Sandra L, "Children as Consumers: Advertising and Marketing", Journal of Consumer Research, 2008, 205-234.

Cauberghe, Veroline, Patrick De Pelsmacker, Liselot Hudders, Katarina Panic, and Destoop Karl, Reclamewijsheid bij kinderen en Jongeren: onderzoeksrapport in opdracht van Vlaams ministerie van Cultuur, Jeugd, Sport en Media, 2012.

Cheyne, Andrew D., Lori Dorfman, Eliana Bukofzer, and Jennifer L. Harris, "Marketing sugary cereals to children in the digital age: a content analysis of 17 child-targeted websites", Journal of Health Communication, 2013 (18), 563-582. DOI:10.1080/10810730.2012.743622.

Clifford, Damian, and Valerie Verdoodt, "Ad-blocking-the dark side of consumer empowerment: a new hope or will the empire strike back", BILETA Conference Hertfordshire, 2017.

Council of Europe, Recommendation Rec(2006) 12 of the Committee of Ministers to member states on empowering children in the new information and communications environment, 2006.

Council of Europe, Recommendation CM/Rec(2014)6 of the Committee of Ministers to member States on a Guide to human rights for Internet users, 2014.

Council of Europe, Strategy on the Rights of the Child 2016-2021, 2016.

Council of Europe, Internet Governance - Council of Europe Strategy 2016-2019: Democracy, human rights and the rule of law in the digital world, 2016. 
Council of Europe (Parliamentary Assembly), Recommendation 2092 (2016) - Fighting the over-sexualisation of children, 2016.

Daems, Kristien, and Patrick De Pelsmacker, Marketing communication techniques aimed at children and teenagers. A research report within the frame of the AdLit Project, 2015.

Daly, Aoife, A Commentary on the United Nations Convention on the Rights of the Child, Article 15: The Right to Freedom of Association and to Freedom of Peaceful Assembly, (Brill, 2016). DOI:10.1163/9789004258839.

De Pauw, Pieter, Ralf De Wolf, Liselot Hudders, and Veroline Cauberghe, "From persuasive messages to tactics: Exploring children's knowledge and judgement of new advertising formats", New Media and Society, 2017, 1-25. DOI:o0r.g1/107.171/1774/6114461444841871772288425.

EDPS, Opinion of the European Data Protection Supervisor on the Communication from the Commission to the European Parliament, the Council, the European Economic and Social Committee and the Committee of the Regions - "European Strategy for a Better Internet for Children.", (2012)

Eekelaar, John, "The Interests of the Child and the Child's Wishes: The Role of Dynamic Selfdeterminism", International Journal of Law, Policy and the Family 1994 (8), 42-61. DOI:10.1093/lawfam/8.1.42.

European Court of Human Rights, Case of Application no. 48898/99 of 25 July 2001 (Second Section), 2012.

European Parliament (Committee on Culture and Education), Report on protecting children in the digital world (2012/2068(INI)), 2012.

Fortin, Jane, Children's Rights and the Developing Law, (Cambridge University Press, 2003).

Global Privacy Enforcement Network, Children's Privacy Sweep, 2015.

Grimes, Sara M, "Kids' Ad Play: Regulating Children's Advergames in the Converging Media Context", International Journal of Communications Law and Policy 2008 (8): 162-178.

Gunter, Barrie, Kids and branding in a digital world. (Manchester: Manchester University Press, 2016).

Hellemans, Liesbeth, Eva Lievens, and Peggy Valcke, "Playing hide-and-seek? A legal perspective on the complex distinction between commercial and editorial content in hybrid advertising formats", info 2015 (17), 19-34. DOI:10.1108/info-05-2015-0026.

Hodgkin, Rachel, and Peter Newell, Implementation Handbook for the Convention on the Rights of the Child: Fully Revised Third Edition, (UNICEF, 2007).

van der Hof, Simone, and Corien Prins, "Personalisation and its Influence on Identities, Behaviour and Social Values", in Profiling the European Citizen, 111-127 (Dordrecht: 
Springer, 2008). DOI:10.1007/978-1-4020-6914-7_6.

Kabel, Jan, Swings on the Horizontal - The Search for Consistency in European Advertising Law. Legal Observations of the European Audiovisual Observatory, (Council of Europe, European Audiovisual Observatory, 1994).

Kirsch, Matthew S, "Do-Not-Track: Revising the EU's Data Protection Framework to Require Meaningful Consent for Behavioral Advertising", Rich. JL \& Tech. 2011 (18), 1.

Lansdown, Gerison, The evolving capacities of the child. Save the Children, (Florence: UNICEF, 2005).

Liefaard, Ton, Hepping, K.E., Rap, S.E., and Huijer, J.I, "Het belang van het kind en de hooggespannen verwachtingen van het IVRK" in Hepping, K.E., Rap, S.E. Huijer, J.I (eds.) (Boom Criminologie, 2016).

Lievens, Eva, Protecting Children in the Digital Era, (Brill, 2010). DOI:10.1163/ej.9789004184770.i-586.

Lievens, Eva, "A children's rights perspective on the responsibility of social network site providers", 25th European Regional Conference of the International Telecommunications Society (ITS), Brussels, Belgium, 2014.

Lievens, Eva, Sonia Livingstone, Sarah McLaughlin, Brian O'Neill, and Valerie Verdoodt. "Children's rights and digital technologies", in International Children's Rights Law (Springer, 2018).

Lievens, Eva, and Valerie Verdoodt, "Looking for needles in a haystack: Key issues affecting children's rights in the General Data Protection Regulation" Computer Law \& Security Review 2017. DOI:10.1016/j.clsr.2017.09.007.

Livingstone, Sonia, John Carr, and Jasmina Byrne, "One in Three: Internet Governance and Children's Rights", Paper Series Centre for International Governance Innovation and the Royal Institute of International Affairs, 2015, 22.

Lupiáñez-Villanueva, Francisco, George Gaskell, Giuseppe Veltri, Alexandra Theben, Frans Folkvord, Francesco Bogliacino, Llüisa Fernandez, Ewelina Marek, and Cristiano Codagnone, Study on the impact of marketing through social media, online games and mobile applications on children's behaviour, (European Commission, 2016).

Montgomery, Kathryn C., and Jeff Chester, "Interactive Food and Beverage Marketing: Targeting Adolescents in the Digital Age", Journal of Adolescent Health 2008, 45.

Montgomery, Kathryn C., and Jeff Chester, "Data Protection for Youth in the Digital Age: Developing a Rights-based Global Framework", European Data Protection Law Review 2015 (1), 277-291. DOI:10.21552/EDPL/2015/4/6.

Moore, Elizabeth S, and Victoria J Rideout, "The Online Marketing of Food to Children: Is It Just Fun and Games?", Journal of Public Policy \& Marketing 2007 (26), 202-220. 
DOI:10.1509/jppm.26.2.202.

Nairn, Agnes, and Cordelia Fine, "Who's messing with my mind?: The implications of dualprocess models for the ethics of advertising to children", International Journal of Advertising 2008 (27), 447-470. DOI:10.2501/S0265048708080062.

Nairn, Agnes, and Haiming Hang, Advergames: it's not child's play: a review of research, commissioned by the Family and Parenting Institute, 2012.

Nowak, Manfred, Article 6: the right to life, survival, and development - A Commentary on the United Nations Convention on the Rights of the Child. (Leiden; Boston: Martinus Nijhoff Publishers, 2005).

OECD, The protection of children online - Recommendation of the OECD Council, 2012.

Opree, Suzanna J., Moniek Buijzen, Eva A. van Reijmersdal, and Patti M. Valkenburg, "Children's Advertising Exposure, Advertised Product Desire, and Materialism: A Longitudinal Study", Communication Research $2014 \quad$ (41) 717-735. DOI: $10.1177 / 0093650213479129$.

Peleg, Noam, The Child's Right to Development, (University College London, 2012).

Richards, Neil, Intellectual Privacy: Rethinking Civil Liberties in the Digital Age, Vol. 6. (Oxford: Oxford University Press, 2016).

Rouvroy, Antoinette, and Yves Poullet, "The Right to Informational Self-Determination and the Value of Self-Development: Reassessing the Importance of Privacy for Democracy", in Reinventing Data Protection?, 45-76, (Springer, Dordrecht, 2009). DOI:10.1007/978-1-40209498-9_2.

Rozendaal, Esther, Moniek Buijzen, and Patty Valkenburg, "Children's understanding of advertisers' persuasive tactics", International Journal of Advertising 2011, 329-350. DOI:10.2.S01/IJA-30-2-329-350.

Rozendaal, Esther, Matthew A. Lapierre, Eva A. van Reijmersdal, and Moniek Buijzen, "Reconsidering Advertising Literacy as a Defense Against Advertising Effects", Media Psychology 2011 (14), 333-354. DOI:10.1080/15213269.2011.620540.

Sacino, Sherry Wheatley, A Commentary on the United Nations Convention on the Rights of the Child, Article 17: Access to a Diversity of Mass Media Sources, (Brill, 2011). DOI:10.1163/9789004216921.

Savirimuthu, Joseph, Unfair commercial practies, the consumer child and new technologies: What should we regulate? Some Policy Provocations, 2014, (https://www.liverpool.ac.uk/media/livacuk/law/2-research/ecru/BriefingNote.pdf).

Shaheed, Farida, Report of the Special Rapporteur in the field of cultural rights. A/69/28, 2014.

Smith, Lucy, "Convention on the Rights of the Child: freedom of expression for children", in 
Tarlach McGonagle and Yvonne Donders (eds.), The United Nations and Freedom of Expression and Information: Critical Perspectives, (Cambridge: Cambridge University Press, 2015).

Swepston, Lee, A Commentary on the United Nations Convention on the Rights of the Child, Article 32: Protection from Economic Exploitation, (Brill, 2012). DOI: $10.1163 / 9789004231467$.

Third, Amanda, Delphine Bellerose, Urszula Dawkins, Emma Keltie, and Kari Pihl, Children's rights in the digital age [Documento elettronico]: a download from children around the world, (Melbourne: Young and Well Cooperative Research Centre, 2014).

UN Committee on the Rights of the Child, General Comment No. 12 (2009) The right of the child to be heard, 2009.

UN Committee on the Rights of the Child, General comment No. 16 (2013) on State obligations regarding the impact of the business sector, 2013.

UN Committee on the Rights of the Child, General comment No. 17 (2013) on the right of the child to rest, leisure, play, recreational activities, cultural life and the arts (art. 31), 2013.

UN Committee on the Rights of the Child, General comment No. 14 (2013) on the right of the child to have his or her best interests taken as a primary consideration (art . 3, para .1), 2013.

UN Committee on the Rights of the Child, Report of the 2014 Day of General Discussion "Digital media and children's rights", 2014.

UN Committee on the Rights of the Child, GeneralUNCRC Discussion Day 1993, Economic Exploitation of Children, CRC/C/20, 1993.

UN Committee on the Rights of the Child, General, General Comment No. 1 (2001) Article 29 (1): The aims of education, 2001.

UN Committee on the Rights of the Child, General, General Comment No. 5 (2003) General measures of implementation of the Convention on the Rights of the Child (arts. 4, 42 and 44, para. 6), 2003.

UN Committee on the Rights of the Child, General comment No. 13 (2011) The right of the child to freedom from all forms of violence, 2011.

Vanwesenbeeck, Ini, Ralf De Wolf, Ingrid Lambrecht, Liselot Hudders, Veroline Cauberghe, Britt Adams, Kristien Daems, Minors' advertising literacy in relation to new advertising formats - Identification and assessment of the risks. Research Report in the Frame of the AdLit Project, 2009.

Verdoodt, V, Children's rights and advertising literacy in the digital era: Towards an empowering regulatory framework for commercial communication, (KU Leuven; UGent, 2018). 
Verdoodt, Valerie., and Lievens, Eva, "Targeting children with personalised advertising: how to reconcile the best interests of children and advertisers", in Gert Vermeulen and Eva Lievens (eds), Privacy and Data Protection under Pressure: Transatlantic tensions, EU surveillance, and big data, 313-341 (Antwerp, Apeldoorn, Portland: Maklu, 2017).

Verdoodt, Valerie, Clifford, Damian, and Lievens, Eva "Toying with children's emotions, the new game in town? The legality of advergames in the EU", Computer Law and Security Review 2016 (32), 599-614. DOI:10.1016/j.clsr.2016.05.007.

Verdoodt, Valerie, and Lievens, Eva, "De AVG bekeken vanuit een kinderrechtenperspectief pluspunten, knelpunten \& vraagstukken" Computerrecht 2017.

Verheyde, Mieke, Article 28: the right to education. A Commentary on the United Nations Convention on the Rights of the Child. (Leiden; Boston: Martinus Nijhoff Publishers, 2006).

Voorhoof, Dirk, Media(recht) en kinder(recht)en, (Mys \& Breesch, 1994).

Waiguny, Martin K. J., Michelle R. Nelson, and Ralf Terlutter, "The Relationship of Persuasion Knowledge, Identification of Commercial Intent and Persuasion Outcomes in Advergamesthe Role of Media Context and Presence", Journal of Consumer Policy 2014 (37), 257-277. DOI:10.1007/s10603-013-9227-z.

Weijers, Ido, "Grondslagen van jeugdstrafrecht", n Jeugdstrafrecht in internationaal perspectief, 3de ed. (Den Haag: Boom Lemma uitgevers, 2014).

Willems, Jan, Developmental and Autonomy Rights of Children, Maastricht Series in Human Rights, (Antwerpen: Intersentia, 2007).

Zarouali, Brahim, Michel Walrave, Karolien Poels, Koen Ponnet, and Ini Vanwesenbeeck, "Online reclamewijsheid bij kinderen: herkennen en begrijpen van reclamebanners en de rol van need for cognition en reclamewijsheidslessen", Tijdschrift voor communicatiewetenschap.Houten 2016 (44), 24-45. 